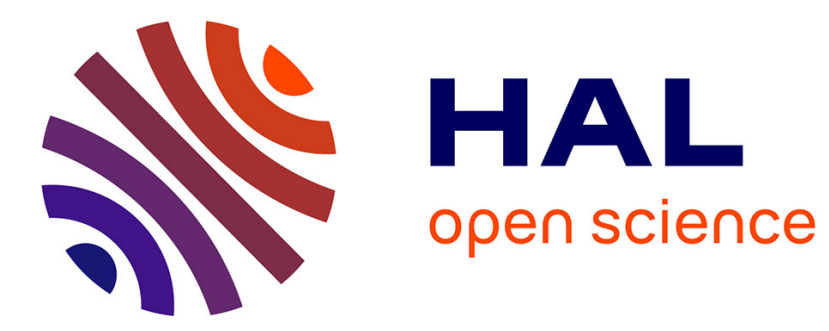

\title{
Synthesis of carbon nanotube-Fe-Al2O3 nanocomposite powders by selective reduction of different Al1.8Fe0.2O3 solid solutions
}

Christophe Laurent, Alain Peigney, Abel Rousset

\section{- To cite this version:}

Christophe Laurent, Alain Peigney, Abel Rousset. Synthesis of carbon nanotube-Fe-Al2O3 nanocomposite powders by selective reduction of different Al1.8Fe0.2O3 solid solutions. Journal of Materials Chemistry, 1998, vol. 8, pp. 1263-1272. 10.1039/a706726g . hal-00939398

\section{HAL Id: hal-00939398 https://hal.science/hal-00939398}

Submitted on 30 Jan 2014

HAL is a multi-disciplinary open access archive for the deposit and dissemination of scientific research documents, whether they are published or not. The documents may come from teaching and research institutions in France or abroad, or from public or private research centers.
L'archive ouverte pluridisciplinaire HAL, est destinée au dépôt et à la diffusion de documents scientifiques de niveau recherche, publiés ou non, émanant des établissements d'enseignement et de recherche français ou étrangers, des laboratoires publics ou privés. 


\section{Open Archive TOULOUSE Archive Ouverte (OATAO)}

OATAO is an open access repository that collects the work of Toulouse researchers and makes it freely available over the web where possible.

This is an author-deposited version published in : http://oatao.univ-toulouse.fr/ Eprints ID : 10821

To link to this article : DOI:10.1039/a706726g

URL : http://dx.doi.org/10.1039/a706726g

\section{To cite this version :}

Laurent, Christophe and Peigney, Alain and Rousset, Abel Synthesis of carbon nanotube-Fe-Al2O3 nanocomposite powders by selective reduction of different All.8Fe0.2O3 solid solutions. (1998) Journal of Materials Chemistry, vol. 8 ( $\mathrm{n}^{\circ} 5$ ). pp. 1263-1272. ISSN 09599428

Any correspondance concerning this service should be sent to the repository administrator: staff-oatao@ listes-diff.inp-toulouse.fr 


\title{
Synthesis of carbon nanotube- $\mathrm{Fe}-\mathrm{Al}_{2} \mathrm{O}_{3}$ nanocomposite powders by selective reduction of different $\mathrm{Al}_{1.8} \mathrm{Fe}_{0.2} \mathrm{O}_{3}$ solid solutions
}

\author{
Ch. Laurent, A. Peigney and A. Rousset \\ Laboratoire de Chimie des Matériaux Inorganiques, ESA CNRS 5070, Université Paul-Sabatier, \\ F 31062 Toulouse cedex 4, France
}

\begin{abstract}
$\mathrm{Al}_{1.8} \mathrm{Fe}_{0.2} \mathrm{O}_{3}$ solid solutions have been prepared as amorphous, $\eta$ (cubic) and $\alpha$ (corundum) phases. The oxides have been reduced in a $\mathrm{H}_{2}-\mathrm{CH}_{4}$ gas mixture at 900 or $1000^{\circ} \mathrm{C}$, giving rise to composite powders containing alumina, $\alpha-$ and $\gamma-\mathrm{Fe}, \mathrm{Fe}{ }_{3} \mathrm{C}$ and different forms of carbon including nanotubes, thick tubes and spheroidal particles. The powders have been investigated using a combination of chemical analysis, X-ray diffraction, Mössbauer spectroscopy, scanning and transmission electron microscopy, thermogravimetric analysis and specific surface area measurements. Using the stable form (corundum) of $\mathrm{Al}_{1.8} \mathrm{Fe}_{0.2} \mathrm{O}_{3}$ as starting material favours the formation of carbon nanotubes compared to the other forms of carbon. This could partly result from the fact that the metal nanoparticles formed upon reduction of the $\alpha$ solid solution, which act as a catalyst for $\mathrm{CH}_{4}$ decomposition and possibly nanotube nucleation, are smaller than when using amorphous or $\eta$ solid solutions. Moreover, the crystallization of these latter compounds during the reduction in some way provokes the entrapment of carbon within the oxide grains. The nanotubes, most of which are less than $10 \mathrm{~nm}$ in diameter, are arranged in bundles several tens of micrometers long.
\end{abstract}

\section{Introduction}

The discovery of carbon nanotubes ${ }^{1}$ triggered a worldwide research effort devoted to improving their synthesis, ${ }^{2-19}$ to determining their structure ${ }^{20-24}$ and to calculating and measuring their physical properties. ${ }^{25-33}$ Particularly, regarding the mechanical properties, the Young's modulus of multi-walled carbon nanotubes has been calculated to be up to 1.4 times that of a graphite whisker, i.e. about $1 \mathrm{TPa},{ }^{34}$ and values derived from thermal vibration experiments performed on several multi-walled carbon nanotubes in a transmission electron microscope are in the $0.4-3.7 \mathrm{TPa}$ range. ${ }^{35}$ Moreover, their flexibility is remarkable ${ }^{36}$ and the bending may be fully reversible up to a critical angle value as large as $110^{\circ}$ for single-walled nanotubes. ${ }^{37}$

Carbon nanotubes are most often prepared by arc-discharge between carbon electrodes in an inert gas atmosphere., ${ }^{1,2}$ Catalytic species such as iron or cobalt can be used during the arc-discharge to improve both the quantity and the length of tubes and to favour the formation of single-shell nanotubes. ${ }^{3-8}$ However, with this process, carbon nanotubes are obtained as a mixture with several other carbon forms, including much amorphous carbon. Thus, purification has to be carried out and the yield of nanotubes is no more than $2 \%{ }^{38}$ Recently, 'ropes' of single-walled carbon nanotubes were obtained by an adapted laser-ablation technique. ${ }^{9,10}$ An alternative method is the catalytic decomposition of hydrocarbons on small metal particles $(\mathrm{Fe}, \mathrm{Co}, \mathrm{Ni}, \mathrm{Cu})$, which produces carbon filaments including some authentic nanotubes. ${ }^{11-19}$ The minimal tube diameter that can be achieved in this way is that of the catalytic particles. In order to maximize the nanotube yield, several authors investigated the influence of the temperature and of the nature of both the catalyst and the treatment atmosphere. ${ }^{13,39,40}$ Using a zeolite-supported Co catalyst, Ivanov et $a l .{ }^{14}$ and Hernadi et $a l .{ }^{41}$ reported carbon tubes only $4 \mathrm{~nm}$ in diameter and tubes of length $60 \mu \mathrm{m}$, but they point out that the longest tubes are also the thickest.

In previous works, we have prepared metal-oxide nanocomposite powders by selective reduction in hydrogen of oxide solid solutions. ${ }^{42-47}$ In these materials, the metal particles $(\mathrm{Cr}$, $\mathrm{Fe}, \mathrm{Co}, \mathrm{Ni}$ and their alloys) are generally smaller than $10 \mathrm{~nm}$ in diameter and are located both inside and at the surface of the matrix grains $\left(\mathrm{Al}_{2} \mathrm{O}_{3}, \mathrm{Cr}_{2} \mathrm{O}_{3}, \mathrm{MgO}, \mathrm{MgAl}_{2} \mathrm{O}_{4}\right)$. We have shown ${ }^{19}$ that when using a hydrogen-hydrocarbon gas mixture instead of pure hydrogen for the reduction of an $\alpha-\mathrm{Al}_{1.9} \mathrm{Fe}_{0.1} \mathrm{O}_{3}$ solid solution, the pristine $\mathrm{Fe}$ nanoparticles formed in situ upon reduction of the very homogeneously dispersed surface $\mathrm{Fe}^{3+}$ ions are active at a size adequate for the catalytic growth of nanotubes. The resulting carbon nanotube-Fe- $\mathrm{Al}_{2} \mathrm{O}_{3}$ composite powder contains a huge amount of single- and multiwalled carbon nanotubes, which have diameters in the $1.5-15 \mathrm{~nm}$ range. The nanotubes are arranged in bundles smaller than $100 \mathrm{~nm}$ in diameter which may be up to $100 \mu \mathrm{m}$ long. It has been calculated that the total bundle length in $1 \mathrm{~g}$ of this powder is equal to about $100000 \mathrm{~km}$. Indeed, the metaloxide grains are uniformly covered by a web-like network of bundles and the powder is so densely agglomerated that it retains the shape of the reduction vessel when transferred to a storage box.

Since the only metal particles active for the catalytic decomposition of the hydrocarbon are those located at the surface of the matrix grains, the active-to-inactive particle ratio could be increased using powders with a high specific surface area such as poorly crystallized or uncrystallized oxide solid solutions. The aim of this work is to determine the influence of the crystallization level of an $\mathrm{Al}_{1.8} \mathrm{Fe}_{0.2} \mathrm{O}_{3}$ solid solution on the formation of carbon nanotubes, in order to increase the tube yield, to maximize their length and to minimize their diameter, with the ultimate objective of obtaining a composite powder suitable for the preparation of dense composite materials that may benefit from the exceptional properties of the carbon nanotubes.

\section{Experimental}

The appropriate amounts of $\left(\mathrm{NH}_{4}\right)_{2}\left(\mathrm{C}_{2} \mathrm{O}_{4}\right) \cdot 2 \mathrm{H}_{2} \mathrm{O}$, $\mathrm{Al}\left(\mathrm{NO}_{3}\right)_{3} \cdot 9 \mathrm{H}_{2} \mathrm{O}$, and $\mathrm{Fe}\left(\mathrm{NO}_{3}\right)_{3} \cdot 9 \mathrm{H}_{2} \mathrm{O}$ were mixed in an aqueous solution heated at $60^{\circ} \mathrm{C}$. The obtained clear solution was cooled to room temperature and rapidly added to an alcoholic medium, in which precipitation of the mixed ammonium oxalate $\left(\mathrm{NH}_{4}\right)_{3}\left[\mathrm{Al}_{0.9} \mathrm{Fe}_{0.1}\left(\mathrm{C}_{2} \mathrm{O}_{4}\right)_{3}\right] \cdot n \mathrm{H}_{2} \mathrm{O}$ occurred immediately. After filtering, washing and oven drying, the oxalate was finely ground and decomposed at $400{ }^{\circ} \mathrm{C}$ for $2 \mathrm{~h}$. This powder will be denoted as C400 hereafter. Samples of the obtained $\mathrm{C} 400$ batch were calcined in air for $2 \mathrm{~h}$, either at $850{ }^{\circ} \mathrm{C}$ (specimen $\mathrm{C} 850$ ) or at $1100^{\circ} \mathrm{C}$ (powder $\mathrm{C} 1100$ ). The 
three different oxide powders were reduced in a $\mathrm{H}_{2}-\mathrm{CH}_{4}$ gas mixture $\left(6 \mathrm{~mol}_{0} \% \mathrm{CH}_{4}\right)$ during $4 \mathrm{~h}$ at $900{ }^{\circ} \mathrm{C}$ or at $1000{ }^{\circ} \mathrm{C}$ (specimens denoted C400/R900, C400/R1000 etc.), giving rise to the carbon-metal-oxide composite powders.

The materials were studied using scanning and transmission electron microscopy (SEM and TEM), X-ray diffraction (XRD) using $\mathrm{Co}-\mathrm{K} \alpha$ radiation $(\lambda=0.17902 \mathrm{~nm})$ and ${ }^{57} \mathrm{Fe}$ Mössbauer spectroscopy. The Mössbauer spectra were recorded at room temperature with a constant acceleration spectrometer using a $50 \mathrm{mCi}{ }^{57} \mathrm{Co}(\mathrm{Rh})$ source; the spectrometer was calibrated by collecting at room temperature the spectrum of a standard Fe foil and the center shift (CS) values quoted hereafter are with reference to this standard. The composite powders were oxidized in air at $850{ }^{\circ} \mathrm{C}$ in order to eliminate all or part of the carbon, as required for the specific surface area study. The specific surface areas of the oxide powders $\left(S_{\mathrm{ss}}\right)$, of the nanocomposite powders obtained after reduction $\left(S_{\mathrm{n}}\right)$ and of the powders oxidized at $850^{\circ} \mathrm{C}\left(S_{\text {on }}\right)$ were measured by the BET method using $\mathrm{N}_{2}$ adsorption at liquid $\mathrm{N}_{2}$ temperature. We used a Micromeritics FlowSorb II 2300 apparatus that gives a specific surface area value from one point (i.e. one adsorbant pressure) and requires calibration. For a given powder, we successively measured $S_{\text {ss }}, S_{\mathrm{n}}$ and $S_{\text {on }}$ using the same calibration. The reproducibility of the results is in the $\pm 5 \%$ range, corresponding to $\pm 10 \%$ for $\Delta S=S_{\mathrm{n}}-S_{\text {on }}$, which accounts for the quantity of carbon nanotubes as detailed later in this paper. Furthermore, we checked that the specific surface area measurements performed by the present method are in good agreement with those performed using a multipoint Micromeritics Accusorb $2100 \mathrm{E}$ apparatus. The carbon content was determined by flash combustion. The oxidation of the nanocomposite powders was investigated by thermogravimetric analysis (TGA) in flowing air (heating rate $1^{\circ} \mathrm{C} \mathrm{min}^{-1}$ ).

\section{Results and Discussion}

\section{Oxide powders}

The XRD patterns of the C400, C850 and C1100 powders are shown in Fig. 1. The pattern of specimen C400 is blank whereas that of the $\mathrm{C} 850$ powder presents wide peaks characteristics of an $\eta-\mathrm{Al}_{1.8} \mathrm{Fe}_{0.2} \mathrm{O}_{3}$ solid solution as well as traces of the (104), (113) and (116) peaks of an $\alpha-\mathrm{Al}_{2} \mathrm{O}_{3}$-type (corundum) phase [Fig. 1(a), (b)]. The $\eta$-phase peaks are very wide (more than $10^{\circ} 2 \theta$ ), reflecting a small crystallite size and a poor crystallization level. For the $\mathrm{C} 1100$ powder, all peaks are in good agreement with an $\alpha-\mathrm{Al}_{1.8} \mathrm{Fe}_{0.2} \mathrm{O}_{3}$ solid solution

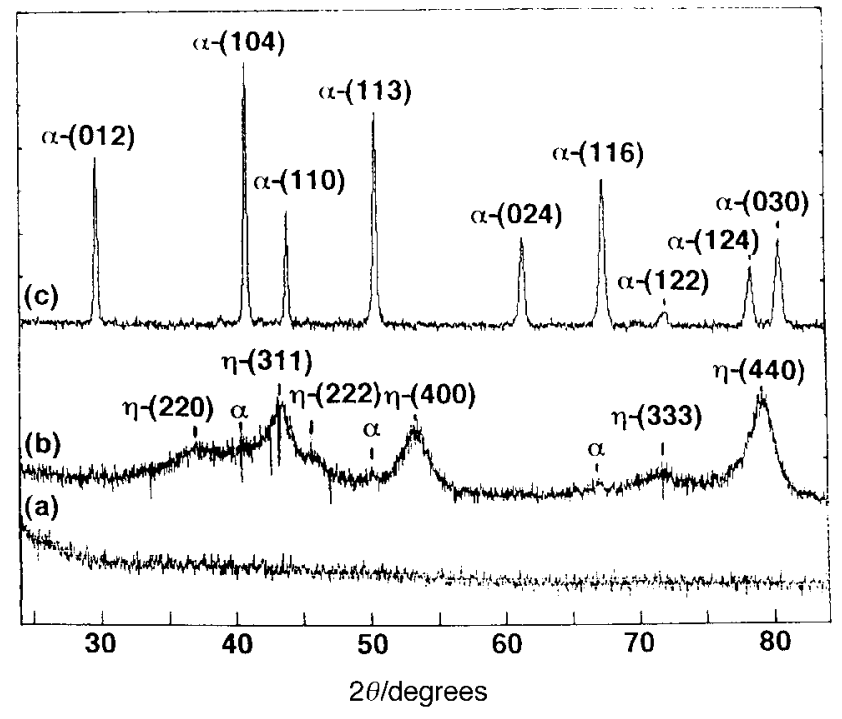

Fig. 1 XRD patterns of the oxide powders prepared at different temperatures: (a) $400{ }^{\circ} \mathrm{C}$; (b) $850{ }^{\circ} \mathrm{C}$; (c) $1100^{\circ} \mathrm{C}$
[Fig. 1(c)]. These results are in agreement with an earlier work ${ }^{48}$ showing that the thermal decomposition at $400{ }^{\circ} \mathrm{C}$ of a mixed oxalate $\left(\mathrm{NH}_{4}\right)_{3}\left[\mathrm{Al}_{0.9} \mathrm{Fe}_{0.1}\left(\mathrm{C}_{2} \mathrm{O}_{4}\right)_{3}\right]$ gives rise to an $\mathrm{X}$ ray amorphous $\mathrm{Al}_{1.8} \mathrm{Fe}_{0.2} \mathrm{O}_{3}$ solid solution, which upon calcination at the appropriate temperature crystallizes into the $\eta$ (cubic) or $\alpha$ (corundum) structure.

SEM observations show that the powders are made up of 10-20 $\mu \mathrm{m}$ agglomerates of submicronic or nanometric primary grains. The specific surface area measured for each oxide powder $\left(S_{\mathrm{ss}}\right.$; Table 1$)$ is consistent with the crystallization level revealed by XRD analysis: $80 \mathrm{~m}^{2} \mathrm{~g}^{-1}$ for the amorphous $\mathrm{Al}_{1.8} \mathrm{Fe}_{0.2} \mathrm{O}_{3}$ solid solution (C400), $30 \mathrm{~m}^{2} \mathrm{~g}^{-1}$ for the poorly crystallized $\eta-\mathrm{Al}_{1.8} \mathrm{Fe}_{0.2} \mathrm{O}_{3}$ powder $(\mathrm{C} 850)$ and $3.1 \mathrm{~m}^{2} \mathrm{~g}^{-1}$ for the $\alpha-\mathrm{Al}_{1.8} \mathrm{Fe}_{0.2} \mathrm{O}_{3}$ powder $(\mathrm{C} 1100)$.

\section{Nanocomposite powders}

X-Ray diffraction. The XRD patterns of the nanocomposite powders prepared by reduction of the solid solutions at 900 or $1000^{\circ} \mathrm{C}$ are shown in Fig. 2. In C400/R900, we observe wide peaks accounting for the presence of different forms of transition alumina $(\eta, \gamma, \theta)$ and only traces of $\alpha-\mathrm{Al}_{2} \mathrm{O}_{3}$. In addition, $\alpha-\mathrm{Fe}$ and $\mathrm{Fe}_{3} \mathrm{C}$ (cementite) are detected. A wide peak which could correspond to the distance between graphene layers $\left(d_{002}=0.34 \mathrm{~nm}\right)$ is also detected. Since neither the $(h k 0)$ nor the other $(h k l)$ reflections, which would have much smaller intensities for nanotubes as well as for graphite, ${ }^{33}$ are detected, it is not possible from this XRD pattern to discriminate between graphite and other graphenic forms of carbon such as nanotubes. Thus we have labelled this peak $\mathrm{C}_{\mathrm{g}}\left(\mathrm{C}_{\text {graphene }}\right)$. The same phases are present in $\mathrm{C} 400 / \mathrm{R} 1000$, but the intensities of the peaks representing $\alpha-\mathrm{Al}_{2} \mathrm{O}_{3}, \alpha-\mathrm{Fe}$ and carbon are much higher. The XRD patterns of C850/R900 and C850/R1000 are similar to those of C400/R900 and C400/R1000, respectively. The main difference is the variation in the proportions of the different forms of alumina on the one hand and in the proportions of $\alpha-\mathrm{Fe}$ and $\mathrm{Fe}_{3} \mathrm{C}$ on the other hand. Also, the (110) peak of $\alpha-\mathrm{Fe}$ is distinctly wider in the C850-derived composites, denoting that the decrease in specific surface area of the oxide solid solution favours the formation of smaller metal particles, as shown previously. ${ }^{42}$ Analysis of the XRD patterns of $\mathrm{C} 1100 / \mathrm{R} 900$ and $\mathrm{C} 1100 / \mathrm{R} 1000$ clearly reveals the presence of $\alpha-\mathrm{Al}_{2} \mathrm{O}_{3}, \alpha-\mathrm{Fe}$ and $\mathrm{Fe}_{3} \mathrm{C}$. The proportions of carbide and, notably, carbon are much lower than in the other powders. $\gamma$-Fe may be present in all or some powders, but is extremely difficult to detect on the XRD patterns because the $\gamma$-Fe (111) diffraction peak $\left(d_{111}=0.208 \mathrm{~nm}\right)$ is probably masked by the base of the corundum (113) peak $\left(d_{113}=\right.$ $0.2085 \mathrm{~nm})$, and more so if $\mathrm{Fe}_{3} \mathrm{C}\left(d_{210}=0.206 \mathrm{~nm}\right)$ is present as well. A $\mathrm{FeAl}_{2} \mathrm{O}_{4}$ spinel phase, which is known to form upon reduction of $\mathrm{Al}_{1.8} \mathrm{Fe}_{0.2} \mathrm{O}_{3}$ in pure $\mathrm{H}_{2}$ at temperatures lower than $1000^{\circ} \mathrm{C}^{44-47}$ is not detected in the $\mathrm{R} 900$ powders. However, one can not rule out its presence in small quantities, particularly in the C400/R900 and C850/R900 specimens, because the $\mathrm{FeAl}_{2} \mathrm{O}_{4}$ main diffraction peaks $\left(d_{113}=0.245 \mathrm{~nm}\right.$, $d_{004}=0.202 \mathrm{~nm}$ and $d_{044}=0.143 \mathrm{~nm}$ ) may be masked by transition-alumina and $\alpha$-Fe peaks.

Carbon content. The carbon content measured in the nanocomposite powders $\left(C_{\mathrm{n}}\right.$; Table 1$)$ is in the $1-20 \mathrm{wt} \%$ range. $C_{\mathrm{n}}$ is much higher in the composites derived from the amorphous $\mathrm{Al}_{1.8} \mathrm{Fe}_{0.2} \mathrm{O}_{3}$ and $\eta-\mathrm{Al}_{1.8} \mathrm{Fe}_{0.2} \mathrm{O}_{3}$ phases than in those derived from the stable $\alpha-\mathrm{Al}_{1.8} \mathrm{Fe}_{0.2} \mathrm{O}_{3}$ phase. This could result from the higher specific surface area of the former powders, which would allow more metal particles to nucleate and grow on the surface of the oxide grains and therefore to be active as catalysts for the decomposition of $\mathrm{CH}_{4}$. We also note that for a given starting powder, the carbon content is higher after reduction at $1000^{\circ} \mathrm{C}$ than after reduction at $900^{\circ} \mathrm{C}$. According to Wagman et al., ${ }^{49}$ the $\mathrm{CH}_{4}$ equilibrium content in $\mathrm{H}_{2}-\mathrm{CH}_{4}$ 
Table 1 Specific surface area $\left(S_{\mathrm{ss}}\right.$ : oxide solid solutions; $S_{\mathrm{n}}$ : nanocomposites; $S_{\text {on }}$ : nanocomposites oxidized at $\left.850^{\circ} \mathrm{C} ; \Delta S=S_{\mathrm{n}}-S_{\text {on }}\right)$ and carbon contents $\left(C_{\mathrm{n}}\right.$ : nanocomposites; $C_{\text {on }}$ : nanocomposites oxidized at $\left.850^{\circ} \mathrm{C}\right)$ of the powders

\begin{tabular}{|c|c|c|c|c|c|c|c|c|}
\hline oxide & $\underset{\substack{\mathrm{m}^{2} \mathrm{~g}^{-1} \\
\mathrm{~g}}}{ }$ & composite & $\underset{/ \mathrm{m}^{2} \mathrm{~g}^{-1}}{S_{\mathrm{n}}}$ & $\underset{/ \mathrm{m}^{2} \mathrm{~g}^{-1}}{S_{\text {on }}}$ & $\begin{array}{c}C_{\mathrm{n}} \\
\text { (wt. \%) }\end{array}$ & $\begin{array}{c}C_{\text {on }} \\
\text { (wt. \%) }\end{array}$ & $\begin{array}{c}\Delta S \\
/ \mathrm{m}^{2} \mathrm{~g}^{-1}\end{array}$ & $\begin{array}{l}\Delta S / C_{\mathrm{n}} \\
/ \mathrm{m}^{2} \mathrm{~g}^{-1}\end{array}$ \\
\hline \multirow[t]{2}{*}{$\mathrm{C} 400$} & \multirow[t]{2}{*}{79.5} & C400/R900 & 23.5 & 20.0 & 13.4 & 0.65 & 3.5 & 26 \\
\hline & & $\mathrm{C} 400 / \mathrm{R} 1000$ & 16.0 & 11.0 & 20.1 & 0.58 & 5.0 & 25 \\
\hline \multirow[t]{2}{*}{ C850 } & \multirow[t]{2}{*}{30.5} & C850/R900 & 44.1 & 39.3 & 8.9 & 0.30 & 4.8 & 54 \\
\hline & & $\mathrm{C} 850 / \mathrm{R} 1000$ & 31.0 & 25.1 & 18.3 & 0.21 & 5.9 & 32 \\
\hline \multirow[t]{2}{*}{$\mathrm{C} 1100$} & \multirow[t]{2}{*}{3.1} & C1100/R900 & 6.7 & 4.1 & 1.65 & 0.00 & 2.6 & 155 \\
\hline & & $\mathrm{C} 1100 / \mathrm{R} 1000$ & 8.4 & 3.5 & 6.2 & 0.00 & 4.9 & 79 \\
\hline
\end{tabular}

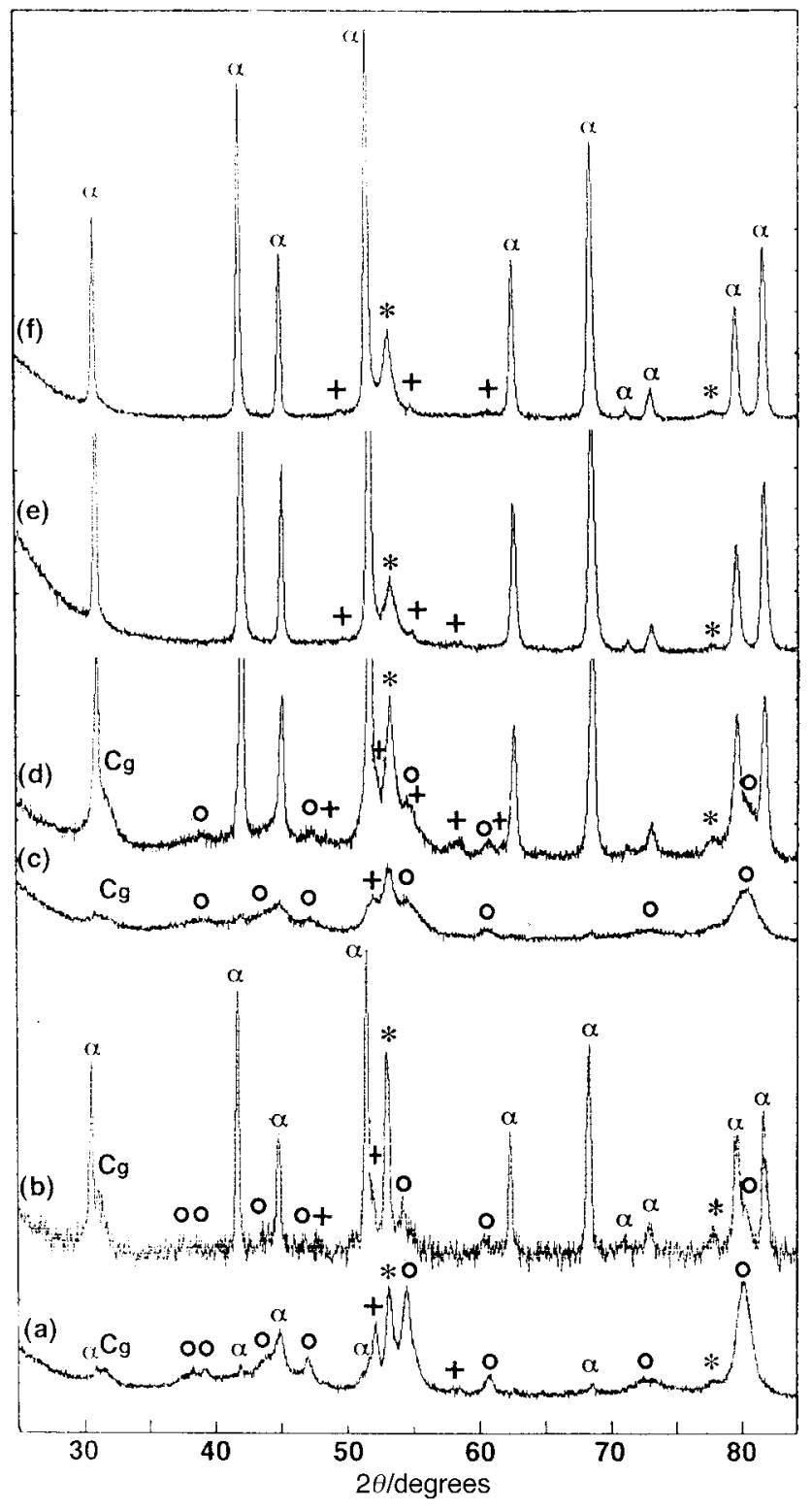

Fig. 2 XRD patterns of the nanocomposite powders prepared by calcination $(\mathrm{C})$ and reduction $(\mathrm{R})$ treatments at different temperatures: (a) C400/R900; (b) C400/R1000; (c) C850/R900; (d) C850/R1000; (e) $\mathrm{C} 1100 / \mathrm{R} 900 ;$ (f) $\mathrm{C} 1100 / \mathrm{R} 1000 ; \alpha$ : $\alpha$-alumina; O: transition alumina; $+: \mathrm{Fe}_{3} \mathrm{C} ; *$ : $\alpha$-Fe; $\mathrm{Cg}$ : corresponding to $d_{002}$ in multi-walled nanotubes and/or in graphite

gas mixtures is lower at $1000{ }^{\circ} \mathrm{C}$ (about $1 \%$ ) than at $900{ }^{\circ} \mathrm{C}$ (about $2 \%$ ). Thus, the $\mathrm{CH}_{4}$ supersaturation level in the gas mixture used in the present study $\left(6 \mathrm{~mol}_{0} \mathrm{CH}_{4}\right)$ is much higher at $1000{ }^{\circ} \mathrm{C}$ than at $900{ }^{\circ} \mathrm{C}$ and consequently more carbon is deposited during the reaction at $1000^{\circ} \mathrm{C}$. Moreover, the increase in carbon content when the reduction temperature is changed from 900 to $1000^{\circ} \mathrm{C}$ is higher when using solid solutions calcined at a higher temperature. This could reflect that the reducibility of the $\mathrm{Fe}^{3+}$ ions substituting in the alumina lattice, and thus the formation of metal nanoparticles, are hampered by a decreasing specific surface area of the oxide powder ${ }^{44}$ and that consequently a $100{ }^{\circ} \mathrm{C}$ increase in reduction temperature has more impact with low specific surface area oxides.

Mössbauer spectroscopy. All composite powders except C400/R1000 were studied by Mössbauer spectroscopy. Each spectrum was fitted assuming it is the sum of different subspectra: a sextet accounting for ferromagnetic $\alpha$-Fe, a sextet representing $\mathrm{Fe}_{3} \mathrm{C}$ and a singlet characteristic of non-ferromagnetic $\mathrm{Fe}$ (Fig. 3 and Table 2). It is noteworthy that neither $\mathrm{Fe}^{3+}$ nor $\mathrm{Fe}^{2+}$ ions were detected on the Mössbauer spectra, even in the composites prepared from the $\mathrm{C} 1100$ oxides, i.e. the less easily reducible phase $\left(\alpha-\mathrm{Al}_{1.8} \mathrm{Fe}_{0.2} \mathrm{O}_{3}\right)$. This shows that the presence of $\mathrm{CH}_{4}$ in the reducing gas mixture tremendously favours the reduction of the iron(III) ions substituting for aluminium in the corundum lattice: indeed, when using pure $\mathrm{H}_{2}, \mathrm{Fe}^{3+}$ contents of 35 and $65 \%$ are measured in $\mathrm{C} 1000 / \mathrm{R} 1000$ and C1200/R1000 composite powders, respectively, ${ }^{44}$ from which one may estimate that the $\mathrm{Fe}^{3+}$ proportion would be of the order of $50 \%$ in a $\mathrm{C} 1100 / \mathrm{R} 1000$ specimen. It has been shown ${ }^{50}$ that treatment at $1300{ }^{\circ} \mathrm{C}$ is necessary to fully reduce the $\mathrm{Fe}^{3+}$ ions substituting for aluminium in the corundum lattice to the metallic state. $\mathrm{Fe}^{2+}$ ions could account for the presence of a phase of the $\mathrm{FeAl}_{2} \mathrm{O}_{4}$ spinel type. ${ }^{44-47}$ As the detection limit in Mössbauer spectroscopy is about 4\%, a very small amount of spinel phase could indeed be present in the R900 composite powders while no corresponding pattern is seen in the spectra. ${ }^{44}$ However, considering the above observation that $\mathrm{CH}_{4}$ strongly favours the formation of metallic $\mathrm{Fe}$, it is reasonable to assume that no residual $\mathrm{Fe}^{3+}$ and $\mathrm{Fe}^{2+}$ ions are present in the composite powders.

Since $\mathrm{Fe}_{3} \mathrm{C}$ has two inequivalent crystallographic sites, ${ }^{51}$ the Mössbauer parameters of the sextet accounting for $\mathrm{Fe}_{3} \mathrm{C}$ correspond to the average of the two $\mathrm{Fe}$-site parameters one may obtain using two sextets for the fit. Our average values are in good agreement with those reported by Le Caër et al. ${ }^{52}$ for bulk $\mathrm{Fe}_{3} \mathrm{C}$ and by $\mathrm{Bi}$ et al. ${ }^{53}$ for $\mathrm{Fe}_{3} \mathrm{C}$ nanoparticles.

The non-ferromagnetic phase of metallic Fe corresponding to the singlet could be either antiferromagnetic, paramagnetic or superparamagnetic $\alpha$-Fe, or $\gamma$-Fe. Paramagnetic $\alpha$-Fe has been observed in $\mathrm{Fe} / \mathrm{Ni}-\mathrm{MgAl}_{2} \mathrm{O}_{4}$ nanocomposite powders ${ }^{54}$ and superparamagnetic $\alpha-\mathrm{Fe}$ was found to be present in some Fe- $\mathrm{Al}_{2} \mathrm{O}_{3}$ specimens. ${ }^{44,45,47}$ However, the negative value of the $\mathrm{CS}$ points towards the face-centered-cubic $\gamma$-Fe phase. This could reflect the formation of a $\gamma-\mathrm{Fe}-\mathrm{C}$ alloy, rather than pure Fe.

It is interesting to note that Baker et al. ${ }^{55}$ have shown that metallic $\mathrm{Fe}$, and not cementite, is the active phase responsible for the formation of carbon nanofilaments. In the present work, the proportions of the different Fe species vary from one powder to another, but analysis of the data does not allow one to draw precise conclusions from their evolution. The very low value $(2 \%)$ observed for $\mathrm{Fe}_{3} \mathrm{C}$ in the $\mathrm{C} 400 / \mathrm{R} 900$ powder is probably a fit artefact and the relatively high proportion of 


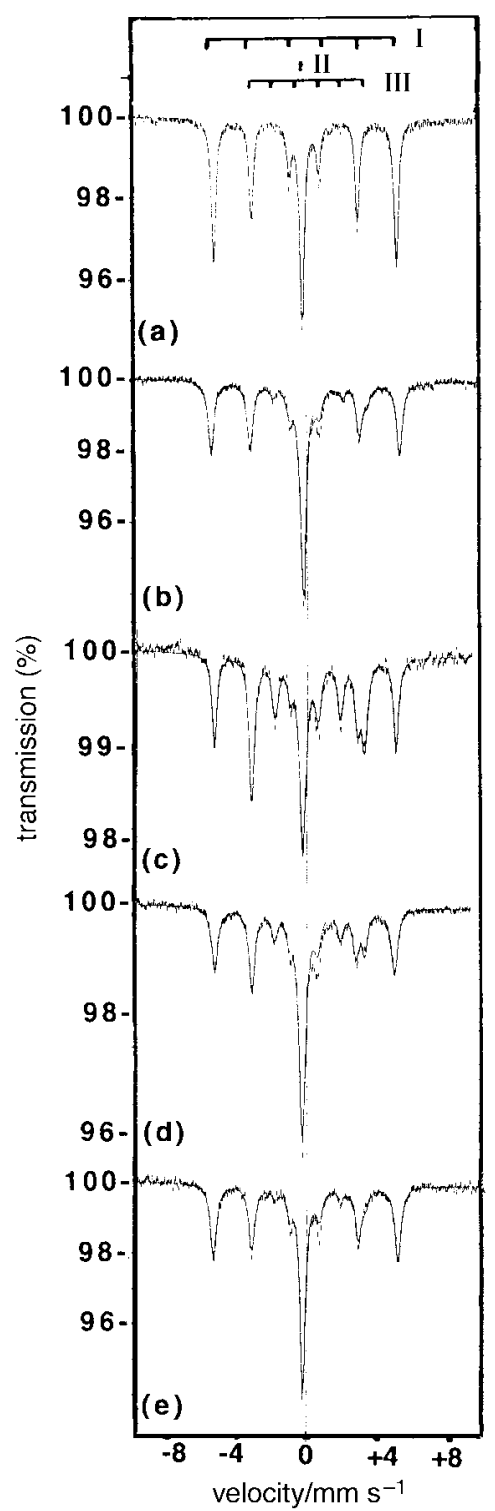

Fig. 3 Mössbauer spectra of the nanocomposite powders prepared by calcination $(\mathrm{C})$ and reduction $(\mathrm{R})$ treatments at different temperatures: (a) C400/R900; (b) C850/R900; (c) C850/R1000; (d) C1100/R900; (e) $\mathrm{C} 1100 / \mathrm{R} 1000$; I: ferromagnetic $\alpha$-Fe; II: non-ferromagnetic $\gamma$-Fe; III: $\mathrm{Fe}_{3} \mathrm{C}$

the same phase in the C850/R1000 powder is in line with the XRD results. The sextet accounting for $\alpha-F e$ is the major component in all specimens and the proportion of the singlet representing $\gamma-\mathrm{Fe}$ is in the $20-35 \%$ range. The intragranular $\mathrm{Fe}$ particles, which number extremely high in such materials, ${ }^{42,45}$ are probably protected from alloying with carbon and crystallize in the stable $\alpha$ form. Moreover, surface particles that form an $\mathrm{Fe}-\mathrm{C}$ alloy but grow to a large enough size undergo the $\gamma-\alpha$ transformation upon cooling from the reduction temperature. The former cause could be preeminent in the composite powders reduced from the stable $\alpha$ solid solutions (C1100/R900 and R1000) and the latter one in the specimens prepared from the high specific surface area oxides, because this favours the formation of surface metal particles.

Electron microscopy. Low-magnification SEM observations of each of the six composite powders show that the matrix grains (about $20 \mu \mathrm{m}$ long) are covered by a web-like network of carbon filaments (Fig. 4), in line with earlier results. ${ }^{19}$ However, higher magnification SEM images [Fig. 5(a)-(f)] clearly reveal some differences depending on the calcination and/or the reduction temperature used for the preparation of the powders. In the C400/R900 powder [Fig. 5(a)], we observe long, tight bundles with a diameter smaller than $50 \mathrm{~nm}$, as well as curved filaments both thicker (up to $100 \mathrm{~nm}$ in diameter) and shorter (about $1 \mu \mathrm{m}$ or less), and some clusters of spheroidal grains in the $20-50 \mathrm{~nm}$ diameter range. The C400/R1000 powder [Fig. 5(b)] presents less carbon bundles and thick filaments but more spheroidal grains which seem to be larger than in the $\mathrm{C} 400 / \mathrm{R} 900$ powder. Both the C850/R900 and C850/R1000 powders [Fig. 5(c), (d)] contain tight bundles and small spheroidal clusters in various quantities from one powder grain to another. Thus, the difference in spheroidal cluster quantities between the two images does not reflects a difference between the two powders. Images of the C1100/R900 and the C1100/R1000 powders [Fig. 5(e)-(f)] show more bundles but interestingly neither thick filaments nor spheroidal clusters have been detected on any observed matrix grain. We also observe homogeneously dispersed nanometric particles which could be $\mathrm{Fe}$ or $\mathrm{Fe}_{3} \mathrm{C}$ particles.

TEM [Fig. 6(a)-(c)] and HREM [Fig. 6(d)-(f)] images of nanocomposite powders show details of the different forms of carbon previously revealed by SEM observations. A thick tube, ${ }^{12}$ irregularly shaped, is shown in the C400/R900 powder

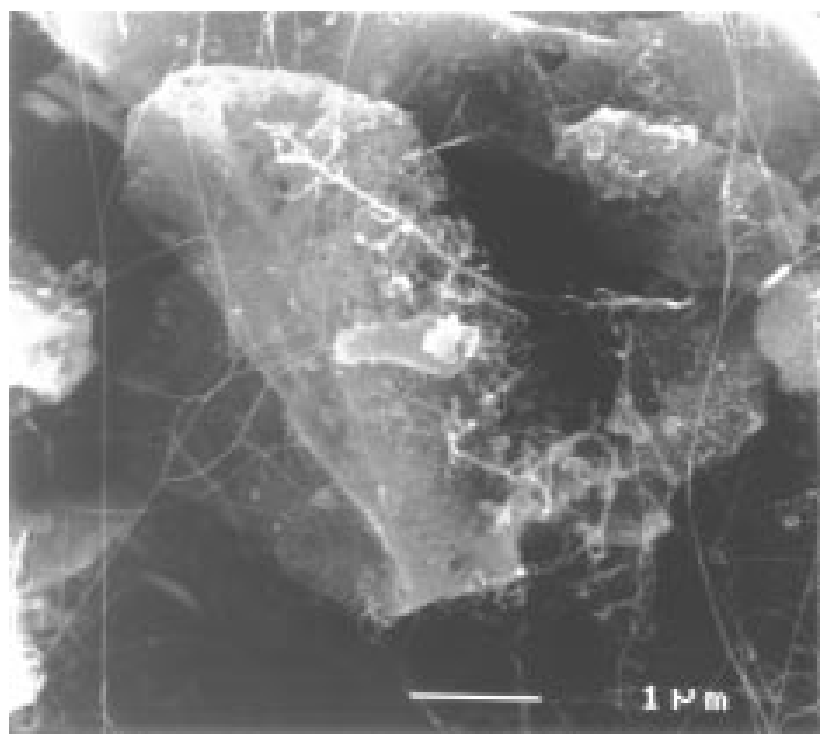

Fig. 4 SEM image showing the network of filaments on a grain of the C400/R1000 powder

Table 2 Room temperature Mössbauer parameters of some nanocomposite powders [ferro: ferromagnetic; non-ferro: non-ferromagnetic; $H$ : hyperfine field/kG; CS: center shift $/ \mathrm{mm} \mathrm{s}^{-1} ; \Gamma$ : half-line width $/ \mathrm{mm} \mathrm{s}^{-1} ; 2 \varepsilon_{\mathrm{Q}}$ : quadrupole shift $/ \mathrm{mm} \mathrm{s}^{-1}, P$ : proportion (\%)

\begin{tabular}{|c|c|c|c|c|c|c|c|c|c|c|c|c|}
\hline \multirow[b]{2}{*}{ specimen } & \multicolumn{4}{|c|}{ ferro $\alpha-\mathrm{Fe}$} & \multicolumn{3}{|c|}{ non-ferro $\mathrm{Fe}$} & \multicolumn{5}{|c|}{$\mathrm{Fe}_{3} \mathrm{C}$} \\
\hline & $\mathrm{CS}$ & $H$ & $\Gamma$ & $P$ & $\mathrm{CS}$ & $\Gamma$ & $P$ & $\mathrm{CS}$ & $H$ & $2 \varepsilon_{\mathrm{Q}}$ & $\Gamma$ & $P$ \\
\hline C400/R900 & 0.00 & 328 & 0.16 & 73 & -0.10 & 0.16 & 25 & 0.10 & 187 & 0.00 & 0.10 & 2 \\
\hline C850/R900 & -0.01 & 333 & 0.20 & 49 & -0.09 & 0.20 & 35 & 0.20 & 205 & 0.06 & 0.27 & 16 \\
\hline C $850 / \mathrm{R} 1000$ & -0.01 & 332 & 0.18 & 38 & -0.09 & 0.19 & 20 & 0.19 & 205 & 0.03 & 0.21 & 42 \\
\hline $\mathrm{C} 1100 / \mathrm{R} 900$ & -0.02 & 328 & 0.22 & 42 & -0.11 & 0.22 & 35 & 0.21 & 204 & 0.06 & 0.20 & 23 \\
\hline C1100/R1000 & -0.01 & 329 & 0.21 & 55 & -0.11 & 0.18 & 32 & 0.19 & 201 & 0.06 & 0.25 & 13 \\
\hline
\end{tabular}



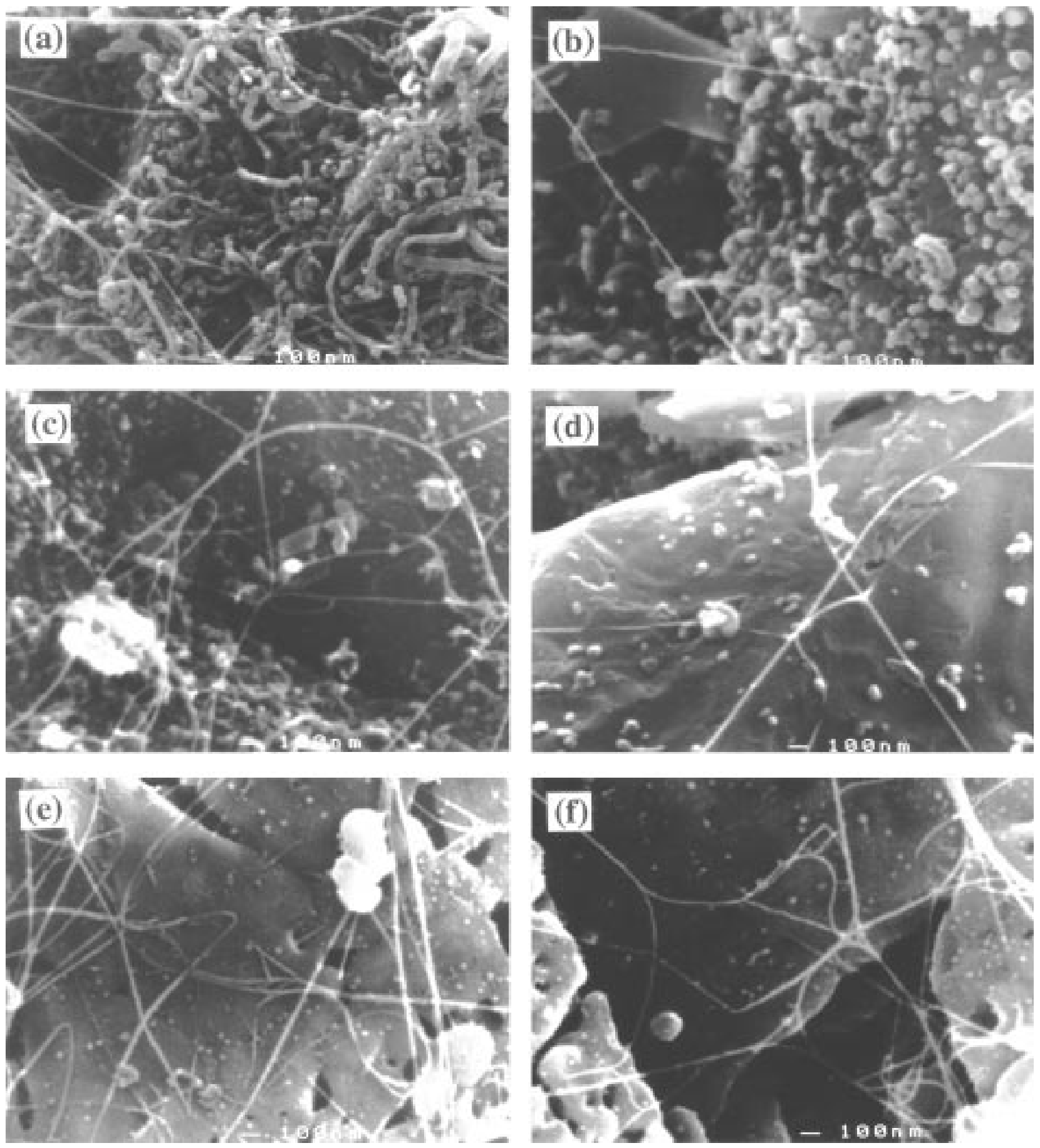

Fig. 5 High magnification SEM images of the nanocomposite powders prepared by calcination $(\mathrm{C})$ and reduction $(\mathrm{R})$ treatments at different temperatures: (a) C400/R900; (b) C400/R1000; (c) C850/R900; (d) C850/R1000; (e) C1100/R900; (f) C1100/R1000

[Fig. 6(a)]. Its inner and outer diameter are about $10 \mathrm{~nm}$ and $50 \mathrm{~nm}$ respectively and the inside cavity is partly filled with elongated $\mathrm{Fe}$ and/or $\mathrm{Fe}_{3} \mathrm{C}$ particles. The short, thick filament in the C400/R1000 powder [Fig. 6(b)] appears to be made up of several hollow forms, one of them containing an Fe and/or $\mathrm{Fe}_{3} \mathrm{C}$ particle. This filament is superimposed with a large $\mathrm{Fe}$ and/or Fe-carbide particle, and is connected to a matrix grain by what seems to be a carbon thin film. In the C1100/R900 powder [Fig. 6(c)], we observe several bundles composed of filaments less than $10 \mathrm{~nm}$ in diameter, a few nanometric irregularly shaped carbon species, and a lot of nanometric Fe and/or Fe-carbide particles, appearing black on the image. We have also observed that the spheroidal clusters $(20-50 \mathrm{~nm}$ in diameter) detected by SEM, particularly in the C400/R1000 powder [Fig. 5(b)], are graphitic carbon nanoparticles, ${ }^{56}$ most of them containing $\mathrm{Fe}$ and/or Fe-carbide particles. HREM observations of the same powder show several Iijima-type ${ }^{1}$ nanotubes [Fig. 6(d)], between 3 and $4 \mathrm{~nm}$ in diameter, made up of two or three concentric layers $\left(d_{002}=0.34 \mathrm{~nm}\right)$ as well as $\mathrm{Fe}$ and/or Fe-carbide particles covered with three well crystallized graphene sheets [Fig. 6(e)]. An image of the C1100/R1000 powder [Fig. 6(f)] reveals a two shell carbon nanotube, $2.8 \mathrm{~nm}$ in diameter, superimposed with an alumina grain and $\mathrm{Fe}$ and/or $\mathrm{Fe}_{3} \mathrm{C}$ particles, the smaller ones (4-8 nm) being probably dispersed inside the oxide grain. A previous study $^{42}$ on the selective reduction in $\mathrm{H}_{2}$ of $\mathrm{Al}_{2-2 x} \mathrm{Fe}_{2 x} \mathrm{O}_{3}$ $(0<x \leqslant 0.2)$ has shown that the size and size distribution of the $\mathrm{Fe}$ particles formed upon reduction mainly depend on the mono- or biphasic nature $(0<x \leqslant 0.1$ or $x>0.1$, respectively) of the starting oxide and also from their specific surface area. Starting with a monophasic oxide such as the present $\mathrm{Al}_{1.8} \mathrm{Fe}_{0.2} \mathrm{O}_{3}$ compound favours a more monomodal size 

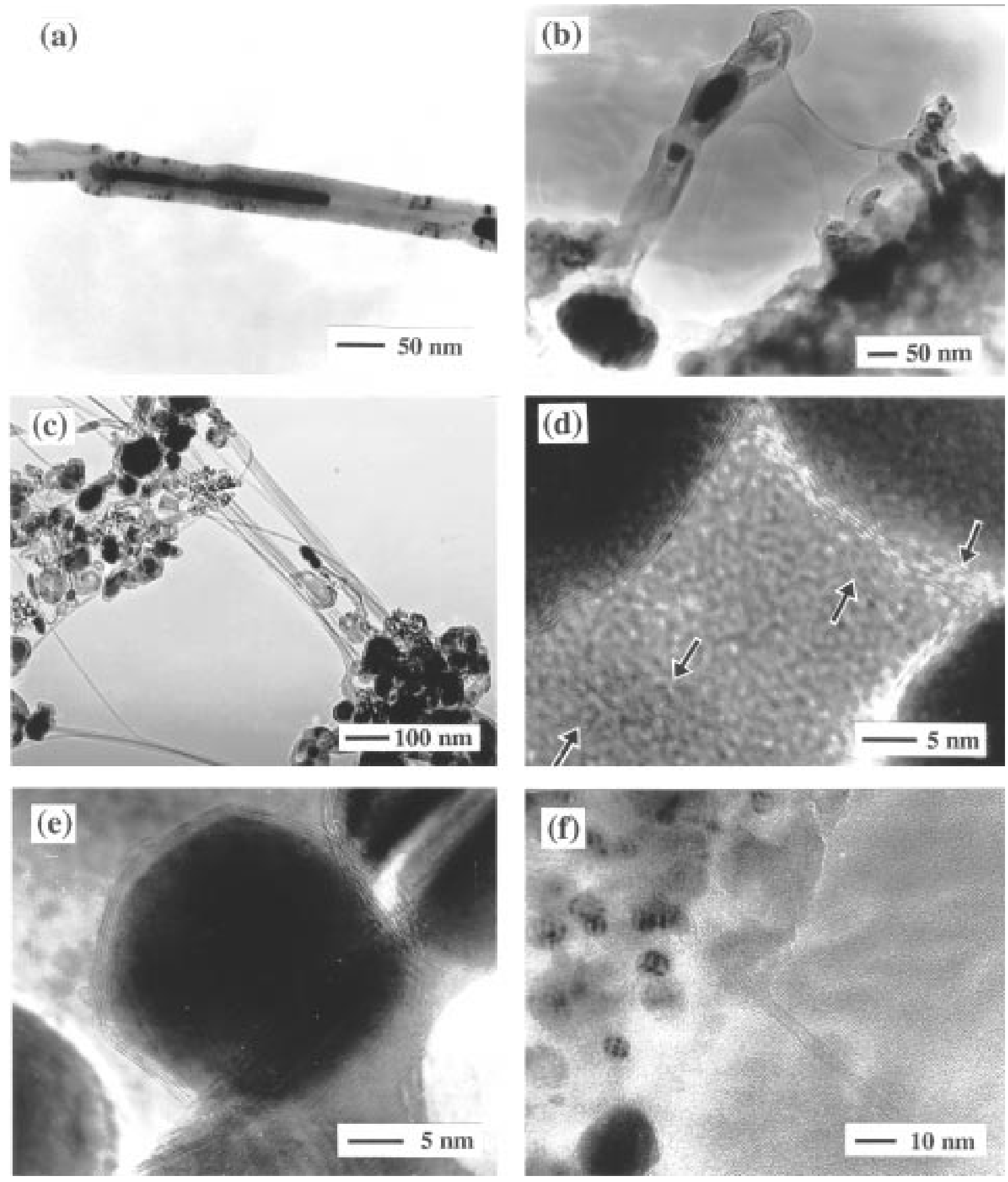

Fig. 6 TEM (a-c) and HREM (d-f) images showing different forms of carbon revealed in the nanocomposite powders: thick tube in the C400/900 powder (a); thick, short filament in the C400/R1000 powder (b); bundles of nanotubes in the C400/900 powder (c); four nanotubes pointed by arrows in the $\mathrm{C} 1100 / \mathrm{R} 900$ powder (d); Fe and/or Fe-carbide particles covered with three well crystallized graphene layers in the C1100/R900 powder (e); a nanotube partially superimposed with an alumina grain containing nanometric $\mathrm{Fe}$ and/or $\mathrm{Fe}_{3} \mathrm{C}$ particles in the $\mathrm{C} 1100 / \mathrm{R} 1000$ powder (f)

distribution and a low specific surface area favours a smaller average size of the metal particles.

Specific surface area measurements. Comparison of the specific surface areas $(S)$ of the solid solutions $\left(S_{\mathrm{ss}}\right.$; Table 1$)$ with those of the nanocomposite powders $\left(S_{\mathrm{n}}\right.$; Table 1$)$ shows that the reduction treatment induces a decrease of $S$ when amorphous starting powders (C400) are used, but that, in contrast, it induces an increase of $S$ when starting from the $\eta$ -
$\mathrm{Al}_{1.8} \mathrm{Fe}_{0.2} \mathrm{O}_{3}(\mathrm{C} 850)$ and $\alpha-\mathrm{Al}_{1.8} \mathrm{Fe}_{0.2} \mathrm{O}_{3}(\mathrm{C} 1100)$ powders. The variations of $S$ could result from the superimposition of two phenomena: on the one hand, crystallization of the oxide and sintering of the primary grains inside the agglomerates lead to a decrease of $S$ when the reduction temperature is higher than the calcination temperature, i.e. when $\mathrm{C} 400$ and $\mathrm{C} 850$ powders are reduced. On the other hand, the formation of carbon species, particularly carbon nanotubes and, to a much lesser degree, the formation of metal nanoparticles at the surface of 
the matrix grains lead to an increase of $S$ upon reduction of all the powders $(\mathrm{C} 400, \mathrm{C} 850$ or $\mathrm{C} 1100)$ ). The former effect outweighs the latter for the C400/R900 and C400/R1000 powders; this is reversed for the C850/R900, C1100/R900 and C1100/R1000 composites. The two processes balance each other in the case of the C850/R1000 powder.

This makes comparisons between the different specimens difficult and does not allow the derivation of precise data on the amount of nanotube formed upon reduction. Therefore, we oxidized the composite powders in air at $850{ }^{\circ} \mathrm{C}$, in order to eliminate all carbon species, and we again measured the specific surface area $\left(S_{\text {on }}\right.$; Table 1$)$. In fact, as we will discuss below, TGA (Fig. 7) and carbon analyses of specimens oxidized at $850^{\circ} \mathrm{C}\left(C_{\text {on }}\right.$; Table 1$)$ show that some carbon remains in some of these samples (C400/R900 or R1000, and C850/R900 or R1000), but in an amount smaller than $10 \%$ of the initial content, which can be neglected. Since the oxidation temperature $\left(850^{\circ} \mathrm{C}\right.$ ) is lower than the reduction temperature (900 or $1000^{\circ} \mathrm{C}$ ), this treatment should not affect the matrix and thus $S_{\text {on }}$ is a good approximation of its specific surface area. We assume that the $\mathrm{Fe}_{2} \mathrm{O}_{3}$ particles formed upon oxidation of the surface $\mathrm{Fe}$ and $\mathrm{Fe}_{3} \mathrm{C}$ nanoparticles ${ }^{57}$ will be of a similar nanometric size and thus that the contribution of the oxide particles to $S_{\text {on }}$ will be roughly similar to that of the Fe and $\mathrm{Fe}_{3} \mathrm{C}$ nanoparticles to $S_{\mathrm{n}}$.

As proposed elsewhere, ${ }^{19}$ the increase in specific surface area per gram of powder, $\Delta S=S_{\mathrm{n}}-S_{\text {on }}$, essentially represents the quantity of nanotubes (more precisely of nanotube bundles) and the increase in specific surface area per gram of carbon, $\Delta S / C_{\mathrm{n}}$, can be considered as 'quality' data, a higher figure for $\Delta S / C_{\mathrm{n}}$ denoting a smaller average tube diameter and/or more carbon in tubular form. Walker et al ${ }^{58,59}$ have also reported specific surface areas in the $35-170 \mathrm{~m}^{2} \mathrm{~g}^{-1}$ range for carbon filaments, which they correlate to a high degree of internal porosity because the geometrical surface area of their filaments (100 $\mathrm{nm}$ in diameter and $1 \mu \mathrm{m}$ long) does not exceed $15 \mathrm{~m}^{2} \mathrm{~g}^{-1}$. In contrast, the present electron microscopy observations have revealed important quantities of very long tubes of nanometric diameter, the geometrical surface area of which is of the order of several hundred $\mathrm{m}^{2} \mathrm{~g}^{-1}$. Other researchers ${ }^{60,61}$ have reported increases in specific surface area upon the catalytic formation of carbon nanofibers, which are in qualitative agreement with the present results.

On the one hand, whatever the initial solid solution $(\mathrm{C} 400$, $\mathrm{C} 850$ or $\mathrm{C} 1100), \Delta S$ is higher when the reduction is performed at $1000{ }^{\circ} \mathrm{C}$ than when it is performed at $900{ }^{\circ} \mathrm{C}$, indicating that a higher $\mathrm{CH}_{4}$ supersaturation level enhances both the quantity of nanotubes and the carbon content $\left(C_{n}\right.$; Table 1$)$. On the other hand, for a given reduction temperature, there is no great difference in $\Delta S$ for the different solid solutions (Table 1). Consequently, the ratio $\Delta S / C_{\mathrm{n}}$ is much higher for C1100/R900 or R1000 powders for which $C_{\mathrm{n}}$ is low; the C1100/R900 powder thus presents the higher quality figure $\left(\Delta S / C_{\mathrm{n}}=155 \mathrm{~m}^{2} \mathrm{~g}^{-1}\right)$. Comparisons of $\Delta S$ and $\Delta S / C_{\mathrm{n}}$ values between C850/R900 and R1000 or between C1100/R900 and R1000 powders (Table 1) show that the increase in quantity obtained when the reduction temperature is increased from 900 to $1000{ }^{\circ} \mathrm{C}$ is detrimental to the quality.

Thermogravimetric analyses. The oxidation of the nanocomposite powders was investigated by thermogravimetric analysis (TGA) in flowing air up to $1400^{\circ} \mathrm{C}$. The TGA curves [Fig. 7(a), (c), (e)] and the corresponding differential thermogravimetric (DTG) curves [Fig. 7(b), (d), (f)] show that the oxidation of the composites occurs in several steps, with both weight gains and weight losses.

For all powders, the first weight gain occurs at temperatures lower than $500{ }^{\circ} \mathrm{C}$ and other gains at temperatures exceeding $600^{\circ} \mathrm{C}$. From the conclusions of previous works on the oxidation of $\mathrm{Fe} / \mathrm{Cr}-\mathrm{Al}_{2} \mathrm{O}_{3}$ and $\mathrm{Fe} / \mathrm{Cr}-\mathrm{Cr}_{2} \mathrm{O}_{3}{ }^{57}$ as well as $\mathrm{Co}-$ and
$\mathrm{Ni}-\mathrm{MgAl}_{2} \mathrm{O}_{4}$ nanocomposite powders, ${ }^{43}$ it is inferred that the low-temperature weight gain (DTG peak in the $225-380{ }^{\circ} \mathrm{C}$ range) corresponds to the oxidation of the $\mathrm{Fe}$ and Fe-carbide particles located at the surface and in the open porosity of the oxide matrix. For the C1100/R900 and C1100/R1000 powders [Fig. 7(e), (f)], the high-temperature weight gain occurs in two steps (DTG peaks at 695 and $1165^{\circ} \mathrm{C}$, and 775 and $1180^{\circ} \mathrm{C}$ respectively) as in $\mathrm{Fe} / \mathrm{Cr}-\mathrm{Al}_{2} \mathrm{O}_{3}{ }^{57}$ nanocomposite powders. It could similarly correspond to the oxidation of the intragranular metal particles. In contrast, for the other powders [Fig. 7(a)-(d)], the high-temperature weight gains are much smaller and only the first step is apparent (DTG peak in the $630-720^{\circ} \mathrm{C}$ range). Two assertions can explain this point. Firstly, in the composite powders derived from the reduction of an amorphous $\mathrm{Al}_{1.8} \mathrm{Fe}_{0.2} \mathrm{O}_{3}$ solid solution (C400) or a poorly crystallized $\eta-\mathrm{Al}_{1.8} \mathrm{Fe}_{0.2} \mathrm{O}_{3}$ powder $(\mathrm{C} 850)$, the $\mathrm{Fe}$ and $\mathrm{Fe}_{3} \mathrm{C}$ particles are mainly located at the surface of the matrix grains and are thus oxidized at a low temperature. Secondly, a hightemperature weight loss takes place and probably masks the end of the first high-temperature weight gain. However it is obvious that above $1100^{\circ} \mathrm{C}$, the weight is constant [Fig. 7(a), (c)], which indicates that the second high-temperature weight gain does not take place for these powders.

The weight losses, which are supposed to represent the oxidation of carbon (free or combined with $\mathrm{Fe}$ ), mainly occur between 350 and $650^{\circ} \mathrm{C}$ and also between 850 and $1000^{\circ} \mathrm{C}$ for some powders (but in a much smaller proportion) [Fig. 7(a)-(f)]. The DTG curves [Fig. 7(b), (d), (f)] show that the first weight loss is generally made up of two or three steps which could represent the oxidation of different forms of carbon. However, the steps are not well enough separated on the TGA and DTG curves to draw any conclusions. Further investigations are in progress to clarify this point.

Comparisons can be made between the total weight loss measured in TGA and the carbon content (Table 1) on the one hand and between the total weight gain measured in TGA and the theoretical weight gain corresponding to the oxidation of all the Fe-containing species as $\mathrm{Fe}_{2} \mathrm{O}_{3}$ on the other hand. Weight losses are always smaller than the corresponding carbon contents, except for the C1100/R900 powder, because gains and losses are generally superimposed. For the same reason, weight gains are always smaller than the theoretical values, which have been calculated assuming that no residual $\mathrm{Fe}^{2+}$ or $\mathrm{Fe}^{3+}$ were present in the powders as indicated by Mössbauer spectroscopy. Note that for the C1100/R900 powder, a weight loss higher than the measured carbon content could be considered as being a consequence of the cumulative errors on the two measurements. Thus, it appears that TGA of the present composite powders can not give quantitative results for either the determination of the content of different carbon forms or the reduction yield of the solid solutions.

Interestingly, the high-temperature weight loss is detected only for the C400- and C850-derived powders [Fig. 7(a)-(d)]. For the C1100-derived specimens [Fig. 7(e)-(f)], this weight loss either does not occur or is masked by the large weight gain arising from the oxidation of intragranular Fe particles. The carbon content was determined for each of the six powders after oxidation in air at $850{ }^{\circ} \mathrm{C}\left(C_{\text {on }}\right.$; Table 1$)$, the temperature at which the high-temperature weight loss phenomenon begins. A small quantity of carbon is measured for each of the four C400- and C850-derived powders, but it is much smaller than the observed high-temperature weight loss [Fig. 7(a), (c)]. For the $\mathrm{C} 1100 / \mathrm{R} 900$ and C1100/R1000 powders, carbon was not detected, and therefore we infer that the weight loss is not masked but rather does not occur.

For the sake of comparison, TGA was performed on an alumina powder previously calcined at $400{ }^{\circ} \mathrm{C}$ and then heattreated at $900{ }^{\circ} \mathrm{C}$ in the $\mathrm{H}_{2}-\mathrm{CH}_{4}$ gas mixture, as the $\mathrm{C} 400 / \mathrm{R} 900$ composite powder. Three steps are detected on the TGA and DGA curves (Fig. 8). At low temperature (DTG peak at 

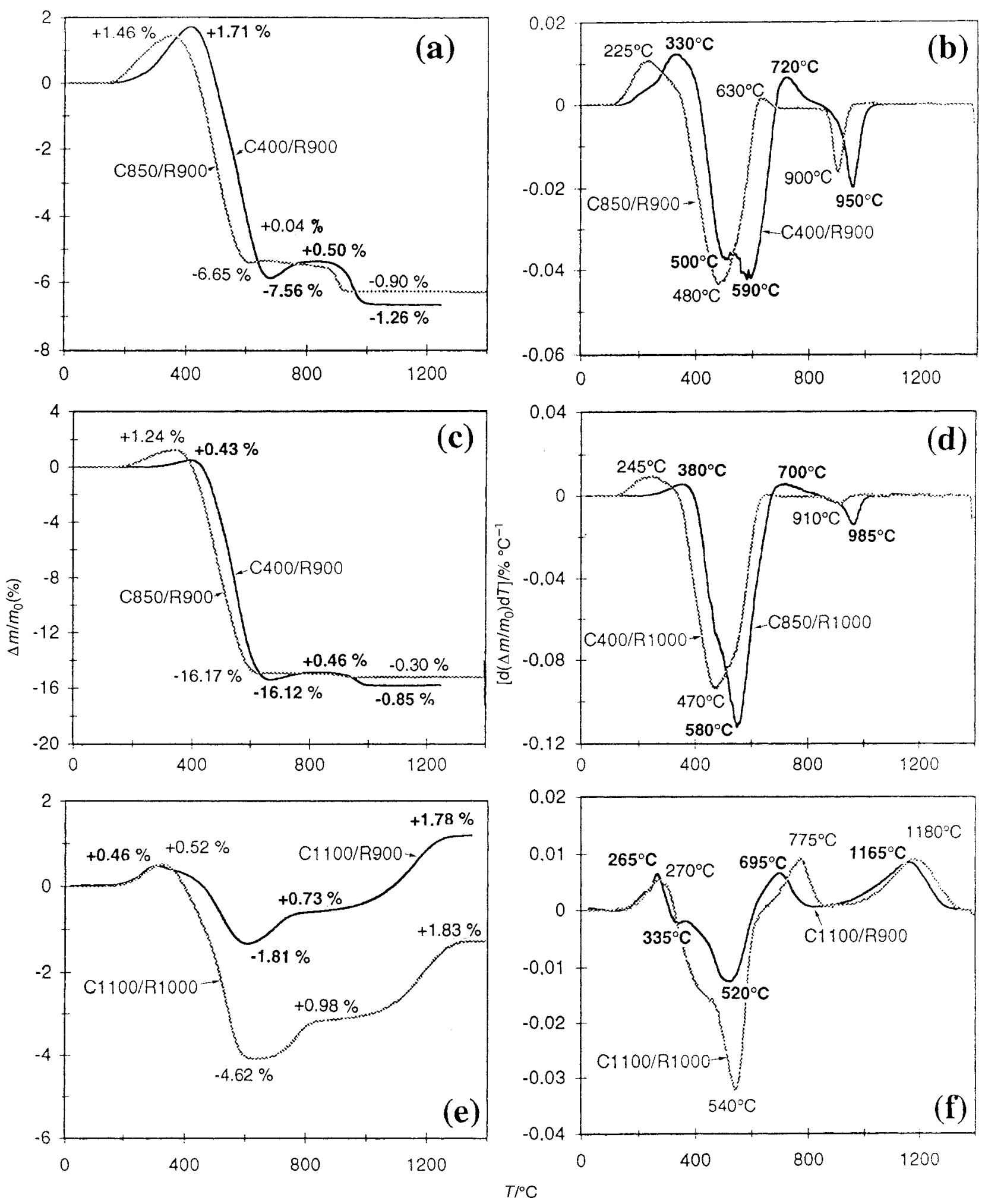

Fig. 7 Thermogravimetry (TGA and DTG) curves measured in flowing air of the nanocomposite powders: C400/R900 and C850/R900 (a, b); C400/R1000 and C850/R1000 (c, d); C1100/R900 and C1100/R1000 (e, f)

$505^{\circ} \mathrm{C}$ ), we observe a small weight loss which probably accounts for the oxidation of crystallized form(s) of carbon located at the surface of the alumina grains. The second step (DTG peak at $900^{\circ} \mathrm{C}$ ) is a weight gain, probably corresponding to an oxygen gain due to the establishment of alumina stoichiometry during the beginning of the crystallization in the $\alpha$-form. Indeed, before this oxidation, the thermal treatment in the $\mathrm{H}_{2}-\mathrm{CH}_{4}$ gas mixture at $900{ }^{\circ} \mathrm{C}$ produced transition alumina, which is probably oxygen-deficient. The third step (DTG peak at $1065^{\circ} \mathrm{C}$ ) is a weight loss, probably due to the oxidation of some carbon entrapped inside the alumina grains. It is noteworthy that the third step is more important for this powder than for the Fe-containing specimens, because no $\mathrm{Fe}$ particles can act as catalyst for $\mathrm{CH}_{4}$ decomposition and therefore preferentially interact with the resulting deposited carbon. In fact, the second and third phenomena may overlap and thus the actual weight loss may be higher than determined by TGA. In spite of this, the total weight loss $(5.93 \%)$ is higher than the measured carbon content $(5.49 \%)$. As pointed out above for the composite powders, the high-temperature weight 


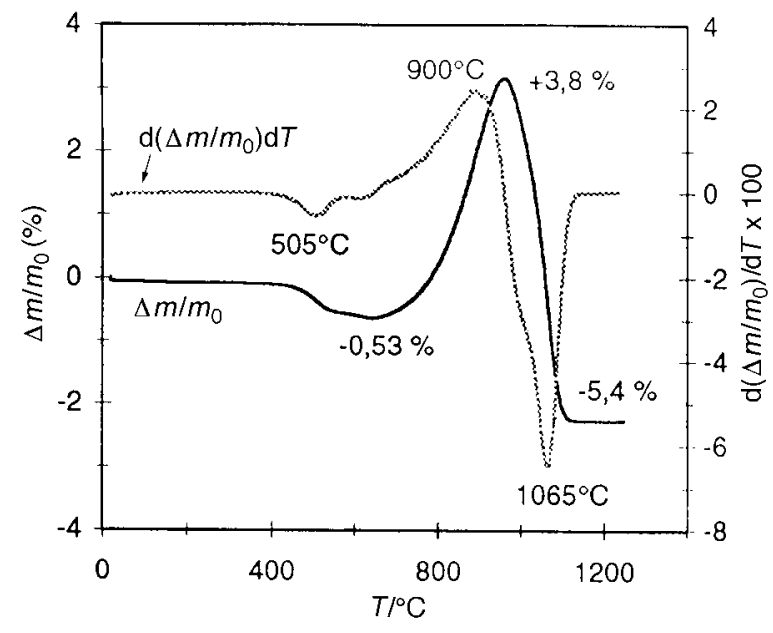

Fig. 8 Thermogravimetry (TGA and DTG) curves measured in flowing air of an alumina powder calcined at $400{ }^{\circ} \mathrm{C}$ and then heat-treated at $900{ }^{\circ} \mathrm{C}$ in $\mathrm{H}_{2}-\mathrm{CH}_{4}$ gas mixture

loss is also higher than the carbon content measured, before this step occurs, in powders oxidized at $850{ }^{\circ} \mathrm{C}$. A possible explanation for these observations is that the flash combustion technique used to determine the carbon contents does not allow the release of all the carbon entrapped inside the alumina grains, thereby decreasing its amount.

Similarly, in the composite powders in which the alumina matrix is not completely crystallized in the $\alpha$-form (C400/R900 and $\mathrm{R} 1000, \mathrm{C} 850 / \mathrm{C} 900$ and $\mathrm{R} 1000$ ), some carbon is probably entrapped inside the transition-alumina grains and it is oxidized only at high temperature.

Influence of the form of the initial $\mathrm{Al}_{1.8} \mathrm{Fe}_{0.2} \mathrm{O}_{3}$ solid solution. These characterization results have shown that, depending on the crystallization level of the initial $\mathrm{Al}_{1.8} \mathrm{Fe}_{0.2} \mathrm{O}_{3}$ solid solution, the reduction process in a $\mathrm{H}_{2}-\mathrm{CH}_{4}$ gas mixture can lead to the formation of several carbon species in the composite powder. The microscopic observations can be directly correlated with macroscopic results, particularly with specific surface area measurements.

When amorphous (C400) or transition (C850) solid solutions are used, carbon species other than bundles of carbon nanotubes appear, including thick tubes, hollow carbon forms and/or clusters of graphitic carbon nanoparticles, most of them containing $\mathrm{Fe}$ and/or $\mathrm{Fe}_{3} \mathrm{C}$ particles. The consequence is a high carbon content $\left(C_{\mathrm{n}}\right.$; Table 1$)$, but a moderate carbon surface $(\Delta S$; Table 1$)$ and thus a low quality parameter $\left(\Delta S / C_{\mathrm{n}}\right.$; Table 1). Since these solid solutions have a relatively high specific surface area $\left(S_{\mathrm{ss}}\right.$; Table 1$)$, most of the $\mathrm{Fe}^{3+}$ ions are located at or near the surface of the grains and are easily reduced to the metallic state, giving rise to a very high number of metal particles which in turn can easily coalesce at the surface of the oxide grains to form much larger particles. ${ }^{42}$ Thus, the diameter of most of these metal particles may be too high for the catalytic formation of nanotubes, in agreement with Baker and Rodriguez ${ }^{12}$ who claim that only sufficiently small (less than $20 \mathrm{~nm}$ in diameter) metal particles can lead to nanotubes. Moreover, we have shown that upon heating in a $\mathrm{H}_{2}-\mathrm{CH}_{4}$ atmosphere, the crystallization of the amorphous or $\eta-\mathrm{Al}_{1.8} \mathrm{Fe}_{0.2} \mathrm{O}_{3}$ solid solutions in some way provokes the entrapment of carbon within the oxide grains. This entrapped carbon, as well as other non-tubular forms of carbon, would probably deteriorate the mechanical properties of massive composites prepared from these powders. Consequently, amorphous (C400) or transition (C850) solid solutions can not be retained as precursors of composite materials including carbon nanotubes.

In contrast, when a stable $\alpha-\mathrm{Al}_{1.8} \mathrm{Fe}_{0.2} \mathrm{O}_{3}$ solid solution
(C1100) is used, carbon seems to be obtained only as bundles of nanotubes, thin graphitic films at the surface of $\mathrm{Fe}$ and/or $\mathrm{Fe}_{3} \mathrm{C}$ particles, and combined with $\mathrm{Fe}$ in cementite. The consequences are a low carbon content $\left(C_{\mathrm{n}}\right.$; Table 1$)$ and a surface of carbon which is rather high $(\Delta S$; Table 1$)$ and thus a rather high quality parameter $\left(\Delta S / C_{n}\right.$; Table 1$)$. This could partly result from the fact that the metal nanoparticles formed upon reduction of the $\alpha$ solid solution, which act as catalyst for $\mathrm{CH}_{4}$ decomposition and possibly nanotube nucleation, are much smaller than when using amorphous or $\eta$ solid solutions ${ }^{42}$ and therefore appear to strongly favour the catalytic deposition of carbon in the form of nanotubes, smaller than $10 \mathrm{~nm}$ in diameter and arranged in bundles several tens of micrometers long, corresponding to aspect ratios as high as $1000-10000 .^{19}$

It should be noted that the macroscopic characteristics of the powders are repeatable provided the specific surface area of the starting solid solution is the same. Reducing a solid solution of a given structure but with a lower specific surface area yields less carbon and thus lower values of $S_{\mathrm{n}}$ and $\Delta S$.

Influence of the reduction temperature. As shown by the above Mössbauer spectroscopy results, $900{ }^{\circ} \mathrm{C}$ is a high enough temperature, in the $\mathrm{H}_{2}-\mathrm{CH}_{4}$ atmosphere, to fully reduce to the metallic state the $\mathrm{Fe}^{3+}$ ions substituting in the different solid solutions. Thus the increase in both carbon content $C_{\mathrm{n}}$ and $\Delta S$ (Table 1) when the reduction temperature is raised from 900 to $1000^{\circ} \mathrm{C}$ are not a consequence of a more complete reduction producing a higher number of catalytic particles, but result from the higher $\mathrm{CH}_{4}$ sursaturation level in the reducing atmosphere. However, a lower quality parameter $\left(\Delta S / C_{\mathrm{n}}\right.$; Table 1$)$ is observed in the $\mathrm{R} 1000$ powders, notably when starting with an $\alpha$-solid solution (C1100).

Thus a compromise has to be found between a high value of $\Delta S$ denoting a high quantity $(\mathrm{C} 1100 / \mathrm{R} 1000)$ and a high value of $\Delta S / C_{\mathrm{n}}$ denoting a high quality (C1100/R900). Since a huge number of carbon nanotubes in the composite powder is desirable to reach a sufficiently high volume fraction, suitable for a possible enhancement of the properties of materials made from these powders, a high reduction temperature $\left(1000{ }^{\circ} \mathrm{C}\right.$ or more) is to be preferred. We have yet to study the influence of other synthesis parameters to enhance the quality of the obtained nanotubes.

\section{Conclusions}

An amorphous $\mathrm{Al}_{1.8} \mathrm{Fe}_{0.2} \mathrm{O}_{3}$ solid solution has been prepared from the precipitation and thermal decomposition of a mixed ammonium oxalate. Calcination in air of the amorphous oxide at the appropriate temperatures produced the $\eta$ (cubic) and the stable $\alpha$ (corundum) forms of $\mathrm{Al}_{1.8} \mathrm{Fe}_{0.2} \mathrm{O}_{3}$. The three oxides have been reduced in a $\mathrm{H}_{2}-\mathrm{CH}_{4}$ gas mixture at 900 or at $1000{ }^{\circ} \mathrm{C}$, giving rise to composite powders containing alumina, $\alpha$ - and $\gamma-\mathrm{Fe}, \mathrm{Fe}_{3} \mathrm{C}$, and several forms of carbon, including carbon nanotubes, thick tubes and clusters of graphitic carbon nanoparticles.

The powders have been studied using a combination of chemical analysis, X-ray diffraction, Mössbauer spectroscopy, scanning and transmission electron microscopy, thermogravimatric analysis and specific surface area measurements. In particular, we have made use of the specific surface area of carbon $(\Delta S$, see text) as a representation of the quantity of carbon nanotubes in a powder and we have considered the ratio of this value to the carbon content $\left(\Delta S / C_{n}\right)$ as a quality value, a higher figure for $\Delta S / C_{\mathrm{n}}$ denoting a smaller average tube diameter and/or more carbon in tubular form.

The presence of $\mathrm{CH}_{4}$ in the reducing gas mixture has been found to markedly favour the reduction of the iron(III) ions substituting for aluminium in the corundum lattice. The composite powders prepared from the amorphous or $\eta$ solid 
solutions contain important quantities of non-tubular carbon, resulting in a poor value of the quality parameter $\Delta S / C_{n}$. Moreover, some carbon is entrapped within the oxide grains upon the crystallization of alumina during the reduction step. This entrapped carbon is more stable than carbon nanotubes with respect to oxidation in air and probably, more generally, with respect to most thermal treatments, which may prove extremely detrimental if those powders were to be used for the production of massive materials by sintering.

In contrast, the composite powders prepared from the stable $\alpha$-solid solution contain carbon essentially in the form of nanotubes, in line with a higher value of $\Delta S / C_{\mathrm{n}}$. This could partly result from the fact that the metal nanoparticles formed upon reduction, which act as catalyst for $\mathrm{CH}_{4}$ decomposition and possibly nanotube nucleation, are smaller than when using amorphous or $\eta$ solid solutions. In these powders, most nanotubes are less than $10 \mathrm{~nm}$ in diameter and they are arranged in bundles several tens of micrometers long.

Starting from an $\alpha$-solid solution, the increase in reduction temperature from 900 to $1000^{\circ} \mathrm{C}$ produces an increase in the amount of nanotubes, probably owing to the higher $\mathrm{CH}_{4}$ supersaturation level in the reduction atmosphere. However, a concomitant decrease in tube quality is also observed, pointing out the need for further studies.

\section{References}

1 S. Iijima, Nature (London), 1991, 354, 56

2 T. W. Ebbesen and P. M. Ajayan, Nature (London), 1992, 358, 220.

3 S. Ijijima and T. Ichihashi, Nature (London), 1993, 363, 603.

4 D. S. Bethune, C. H. Kiang, M. S. de Vries, G. Gorman, R. Savoy, J. Vazquez and R. Beyers, Nature (London), 1993, 363, 605.

5 C. H. Kiang, W. A. Goddard, R. Beyers, J. R. Salem and D. Bethune, J. Phys. Chem. Solids, 1996, 57, 35.

6 S. Seraphin and D. Zhou, Appl. Phys. Lett., 1994, 64, 2087.

7 T. W. Ebbesen, H. J. Lezec, H. Hiura, J. W. Bennett, H. F. Ghaemi and T. Thio, Nature (London), 1996, 382, 54.

8 C. Guerret-Plecourt, Y. Le Bouar, A. Loiseau and H. Pascard, Nature (London), 1994, 372, 761.

9 A. Thess, R. Lee, P. Nikolaev, H. Dai, P. Petit, J. Robert, D. T. Colbert, C. Xu, Y. H. Lee, S. G. Kim, A. G. Rinkler, D. T. Colbert, G. E. Scuseria, D. Tomanek, J. E. Fisher and R. E. Smalley, Science, 1996, 273, 483.

10 S. Witanachchi and P. Mukherjee, J. Vac. Sci. Technol. A, 1995, 3, 1171.

11 M. J. Yacaman, M. M. Yoshida, L. Rendon and J. G. Santiesteban, Appl. Phys. Lett., 1993, 62, 657.

12 R. T. K. Baker and N. Rodriguez, Mater. Res. Soc. Symp. Proc., 1994, 349, 251.

13 S. Herreyre and P. Gadelle, Carbon, 1995, 33, 234.

14 V. Ivanov, A. Fonseca, J. B. Nagy, A. Lucas, P. Lambin, D. Bernaerts and X. B. Zhang, Carbon, 1995, 33, 1727.

15 K. Hernadi, A. Fonseca, J. B. Nagy, D. Bernaerts, J. Riga and A. Lucas, Synth. Met., 1996, 77, 31.

16 A. Fonseca, K. Hernadi, J. B. Nagy, Ph. Lambin and A. Lucas, Carbon, 1995, 33, 1759.

17 M. Endo, K. Takeuchi, K. Kobori, K. Takahashi, H. W. Kroto and A. Sarkar, Carbon, 1995, 33, 873

18 A. Thess, R. Lee, P. Nikolaev, H. Dai, P. Petit, J. Robert, D. T. Colbert, C. Xu, Y. H. Lee, S. G. Kim, A. G. Rinkler, D. T. Colbert, G. E. Scuseria, D. Tomanek, J. E. Fisher and R. E. Smalley, Science, 1996, 273, 483.

19 A. Peigney, Ch. Laurent, F. Dobigeon and A. Rousset, J. Mater. Res., 1997, 12, 613.

20 X. F. Zhang, X. B. Zhang, G. Van Tendeloo, S. Amelinckx, M. Op De Beeck and J. Van Landuyt, J. Crystal Growth, 1993, 130, 368.

21 P. J. Harris, Eur. Microsc. Anal., 1994, 9, 13.

22 G. Hu, X. F. Zhang, D. P. Yu, S. Q. Feng, W. Xu and Z. Zhang, Solid State Commun., 1996, 98, 547.
23 D. Ugarte, Microsc. Microanal. Microstruct., 1993, 4, 505.

24 L. A. Bursill, J. L. Peng and X. D. Fan, Philos. Mag. A, 1995, 71, 1161 .

25 S. J. Tans, M. H. Devoret, H. Dai, A. Thess, R. E. Smalley, L. J. Geerligs and C. Dekker, Nature (London), 1997, 386, 474.

26 A. Y. Kasumov, I. I. Khodos, P. M. Ajayan and C. Colliex, Europhys. Lett., 1996, 34, 429.

27 Y. Nakayama, S. Akita and Y. Shimada, Jpn. J. Appl. Phys., 1995, 34, L10.

28 H. Dai, E. W. Wong and C. M. Lieber, Science, 1996, 272, 523.

29 L. Langer, L. Stockman, J. P. Heremans, V. Bayot, C. H. Olk, C. Van Haesendonck, Y. Bruynserade and J. P. Issi, J. Mater. Res., 1994, 9, 927.

30 X. K. Wang, R. P. H. Chang, A. Pataashinski and J. B. Ketterson, J. Mater. Res., 1994, 9, 1578.

31 D. H. Robertson, D. W. Brenner and J. W. Mintmire, Phys. Rev. $B, 1992,45,12592$.

32 W. A. De Heer, W. S. Bacsa, A. Chatelain, T. Gerfin, R. HumfreyBaker, L. Forro and D. Ugarte, Science, 1995, 268, 845.

33 R. Seshadri, A. Govindaraj, H. N. Aiyer, R. Sen, G. N. Subbanna, A. R. Raju and C. N. R. Rao, Curr. Sci., 1994, 66, 839.

34 S. B. Sinnott, C. T. White and D. W. Brenner, Mater. Res. Soc. Symp. Proc., 1995, 359, 241.

35 M. M. J. Treacy, T. W. Ebbesen and J. M. Gibson, Nature (London), 1996, 381, 678.

36 S. Iijima, C. Brabec, A. Maiti and J. Bernholc, J. Chem. Phys., 1996, 104, 2089.

37 J. F. Despres, E. Daguerre and K. Lafdi, Carbon, 1995, 33, 87.

38 K. Tohji, T. Goto, H. Takahashi, Y. Shinoda, N. Shimizu, B. Jeyadevan, I. Matsuoka, Y. Saito, A. Kasuhka, T. Oshuna, K. Hiraga and Y. Nishina, Nature (London), 1996, 383, 679.

39 R. T. K. Baker, P. S. Harris, R. B. Thomas and R. J. Waite, J. Catal., 1993, 30, 86

40 A. Oberlin, M. Endo and T. Koyama, J. Crystal Growth, 1976, 32, 335 .

41 K. Hernadi, A. Fonseca, J. B. Nagy, D. Bernaerts, A. Fudala and A. A. Lucas, Zeolites, 1996, 17, 416 .

42 X. Devaux, Ch. Laurent and A. Rousset, Nanostruct. Mater., 1993, 2, 339 .

43 O. Quénard, Ch. Laurent, M. Brieu and A. Rousset, Nanostruct. Mater., 1996, 7, 497.

44 Ch. Laurent, A. Rousset, M. Verelst, K. R. Kannan, A. R. Raju and C. N. R. Rao, J. Mater. Chem., 1993, 3, 513.

45 M. Verelst, K. R. Kannan, G. N. Subbanna, C. N. R. Rao, Ch. Laurent and A. Rousset, J. Mater. Res., 1992, 7, 3072.

46 X. Devaux, Ch. Laurent, M. Brieu and A. Rousset, J. Alloys Compd., 1992, 188, 179.

47 A. Marchand, X. Devaux, B. Barbara, P. Mollard, M. Brieu and A. Rousset, J. Mater. Sci., 1993, 28, 2217.

48 A. Rousset and J. Paris, Bull. Soc. Chim. Fr., 1967, 10, 388.

49 D. Wagmann, J. E. Kilpatrick, W. J. Taylor, K. S. Pitzer and F. D. Rossini, J. Res. Natl. Bur. Stand., 1945, 34, 143.

50 Ch. Laurent, J. J. Demai, A. Rousset, K. R. Kannan and C. N. R. Rao, J. Mater. Res., 1994, 9, 229.

51 H. L. Yakel, Int. Met. Rev., 1985, 30, 17.

52 G. Le Caër, J. M. Dubois and J. P. Sénateur, J. Solid State Chem., 1976, 19, 19.

53 X. X. Bi, B. Ganguly, G. P. Huffman, F. E. Huggins, M. Endo and P. C. Eklund, J. Mater. Res., 1993, 8, 1666.

54 O. Quénard, E. De Grave, Ch. Laurent and A. Rousset, J. Mater. Chem., 1997, 7, 2457.

55 R. T. K. Baker, J. R. Alonzo, J. A. Dumesic and D. J. C. Yates, J. Catal., 1977, 74, 82

56 Y. Saito, Carbon, 1995, 33, 979

57 Ch. Laurent, Ch. Blaszczyk, M. Brieu and A. Rousset, Nanostruct. Mater., 1995, 6, 317.

58 P. L. Walker, Jr., J. F. Rakszawski and G. R. Imperial, J. Phys. Chem., 1959, 63, 133.

59 P. L. Walker, Jr., J. F. Rakszawski and G. R. Imperial, J. Phys Chem., 1959, 63, 140.

60 N. M. Rodriguez, M.-S. Kim and R. T. K. Baker, J. Phys. Chem., $1994,98,13108$

61 W. B. Downs and R. T. K. Baker, J. Mater. Res., 1995, 10, 625. 